\title{
Choroid Plexus Potassium Cotransport: Modulation by Osmotic Stress and External Potassium
}

\author{
Richard F. Keep and Jianming Xiang \\ Department of Surgery (Neurosurgery), University of Michigan, Ann Arbor, Michigan, U.S.A.
}

\begin{abstract}
The choroid plexuses are involved in CSF secretion and CSF $\mathrm{K}$ homeostasis. This study examines the potential role of $\mathrm{K}$ cotransport in these two processes using isolated rat lateral ventricle choroid plexuses. Bumetanide-sensitive ${ }^{86} \mathrm{Rb}$ influx and efflux were measured to assess the response of $\mathrm{K}$ cotransport to changes in media osmolality and $\mathrm{K}$ concentration. Alterations in osmolality had no effect on $\mathrm{K}$ uptake (in the presence or absence of bumetanide). However, the efflux rate constant for $\mathrm{K}$ was $0.29 \pm 0.02,0.44 \pm 0.04$, and $0.84 \pm 0.06$ $\mathrm{min}^{1}$ in 240,300 , and $424 \mathrm{mOsm} / \mathrm{kg}$ solutions, respectively $(p<0.001)$. This increase in efflux with osmolality, an opposite effect to that found in many cells, was solely due to enhanced $\mathrm{K}$ cotransport. The increased cotransport may be involved in limiting brain shrinkage during hyperosmotic stress if the cotransporter is present on the apical membrane. The rate of bumetanide-sensitive efflux was unaffected by changes in external $[\mathrm{K}]$. However, the rate of $\mathrm{K}$ uptake (measured on return to normal [K] media) was reduced gradually by exposure to low $[K]$. It was 21 $\pm 1,19 \pm 3,13 \pm 2$, and $6 \pm 1 \mathrm{nmol} / \mathrm{mg} / \mathrm{min}$ after 0,10 , 30 , and 60 -min exposure to $1 \mathrm{mMK}$. Sixty minutes of exposure to $1 \mathrm{mM}[\mathrm{K}]$ abolished the bumetanide-sensitive $\mathrm{K}$ uptake present in plexuses exposed continually to normal media. This modulation of $\mathrm{K}$ cotransport by external $[\mathrm{K}]$ may be important in CSF $\mathrm{K}$ homeostasis by limiting $\mathrm{K}$ loss from the CSF if CSF $[\mathrm{K}]$ is low. Key Words: CSF-Choroid plexus-Potassium cotransport-Potassium homeostasis $-{ }^{86} \mathrm{Rb}-$ Volume regulation.

J. Neurochem. 64, 2747-2754 (1995).
\end{abstract}

The choroid plexuses, situated in the lateral, third, and fourth ventricles, form part of the blood-CSF barrier. They are the main site of CSF production and they are also involved in the regulation of CSF ionic composition (reviewed in Bradbury, 1979). For example, the concentration of potassium $([\mathrm{K}]$ ) in the CSF is maintained constant during fluctuations in plasma [K] (e.g., Bradbury and Kleeman, 1967; Jones and Keep, 1987; Stummer et al., 1994).

Recently, a number of studies have indicated the presence of both inward- and outward-directed $\mathrm{K} \mathrm{co-}$ transport in isolated choroid plexuses (Bairamian et al., 1991; Zeuthen, 1991a; Johanson and Preston,
1994: Keep et al., 1994). Bumetanide-sensitive cotransport comprises $\sim 45 \%$ of $\mathrm{K}$ uptake and $80 \%$ of $\mathrm{K}$ efflux in isolated rat choroid plexuses (Keep et al., 1994 ). Both inward and outward cotransport are probably of the $\mathrm{Na} / \mathrm{K} / 2 \mathrm{Cl}$ form and may indeed be the same transporter operating in both directions (Keep et al., 1994).

Despite the predominance of cotransport in $\mathrm{K}$ movement at the choroid plexus, the function of this transport is uncertain. In view of the importance of the choroid plexus in CSF $\mathrm{K}$ regulation and the known role of $\mathrm{Na} / \mathrm{K} / 2 \mathrm{Cl}$ cotransport in cell volume regulation in other issues, we have examined the potential modulation of cotransport by $[\mathrm{K}]$ and osmolality in the isolated rat choroid plexus.

\section{MATERIALS AND METHODS}

Experiments were performed on lateral ventricle choroid plexuses isolated from pentobarbital $(50 \mathrm{mg} / \mathrm{kg})$-anesthetized Sprague-Dawley rats aged between 30 and 50 days. For each data point, a rat was decapitated, the plexuses dissected, weighed (influx studies only), and transferred to control buffer at $37^{\circ} \mathrm{C}$. There was a 5 -min recovery period before the beginning of any experiment. Measurements on the rate of $\mathrm{K}$ uptake and efflux in choroid plexuses were then made with ${ }^{86} \mathrm{Rb}$ rather than ${ }^{42} \mathrm{~K}$ because of its longer half-life. The rate of movement of these two ions by many transport systems, including the choroid plexus $\mathrm{K}$ cotransporter (Keep et al., 1994), is similar.

\section{Rubidium influx and efflux}

These methods are presented in detail in Keep et al. (1994). In brief, for "Rb uptake, measurements were made over $30 \mathrm{~s}$ using $\left[{ }^{3} \mathrm{H}\right]$ mannitol (osmolality experiments) or $\left[{ }^{3} \mathrm{H}\right]$ dextran ( $\mathrm{K}$ experiments) to correct for isotope in the extracellular space. Uptake was terminated by transferring the plexus to iced control buffer and filtering under reduced pressure. The filters were washed three times with the samc

Received August 12, 1994; revised manuseript received November 23, 1994; accepted December 2, 1994.

Address correspondence and reprint requests to Dr. R. F. Keep at Department of Surgery (Neurosurgery). University of Michigan, R5605 Kresge I, Ann Arbor, MI 48109-0532, U.S.A.

Abbreviation used: $[\mathrm{K}]$. concentration of potassium. 
buffer. The filters and choroid plexuses were then soaked in $1 M$ hyamine hydroxide (a tissue solubilizer) before the addition of scintillation cocktail (Cytoscint) and counting with a dual-channel liquid scintillation counter (Beckman LS 3801; Fullerton, CA, U.S.A.).

The rate of uptake of ${ }^{86} \mathrm{Rb}$ into choroid plexus, in microliters per milligram per minute, was corrected for extraccllular space. Then, assuming that ${ }^{86} \mathrm{Rb}$ is transported into the choroid plexus at the same rate as $K$, the rate of uptake of $K$ (nanomoles per milligram per minute) was calculated by multiplying by the $\mathrm{K}$ concentration of the external medium.

For efflux measurements, plexuses were allowed to accumulate ${ }^{86} \mathrm{Rb}$ for $10 \mathrm{~min}$, washed in control buffer for $15 \mathrm{~s}$, and then transferred to efflux buffer. After a 30 -s preincubation period, the efflux buffer was sampled at 30-s intervals for 2 min. Hyamine hydroxide $(1 M)$ was then added to the final solution plus choroid plexus. This solution was then heated at $70^{\circ} \mathrm{C}$, sampled, and the final choroid plexus isotope contents were determined after addition of scintillation cocktail.

For cach experiment, the fraction of the initial choroid plexus ${ }^{86} \mathrm{Rb}$ content, corrected for extracellular space, was calculated for each time point $(0,0.5,1,1.5$, and $2 \mathrm{~min})$. The natural logarithms of these values were plotted against time and the slope determined by linear regression analysis. The slopes of these plots equal the efflux rate constants $\left(K_{6}\right)$ with units of $\min ^{-1}$.

\section{Experimental protocol: effect of osmolality}

For experiments examining the effects of osmolality on $\mathrm{K}$ transport, plexuses were exposed to the media of different osmolalities for $10 \mathrm{~min}$ before and during the measurement of the rate of ${ }^{x /} \mathrm{Rb}$ uptake or efflux. For efflux studies, this exposure was during the ${ }^{8 t} \mathrm{Rb}$-uptake phase of the experiment. Bumctanide $(30 \mu M)$ and ouabain $(5 \mathrm{~m} M)$ were used to inhibit cotransport or Na,K-ATPase activity, respectively. These drugs were present for $30 \mathrm{~s}$ before the onset of and during the uptake or efflux measurement.

\section{Experimental protocol: effect of external [ $\mathrm{K}$ ]}

To examine the effect of exposure to media of different $K$ concentrations on the rate of $K$ efflux, plexuses were exposed to $1,2.9$, or $6 \mathrm{mMK}$ for $1 \mathrm{~h}$. The rate of efflux was then measured either in those solutions or $30 \mathrm{~s}$ after return to control CSF $(2.9 \mathrm{~m} M \mathrm{~K})$.

Parmelee et al. (1991) have already shown that K uptake into rat choroid plexus shows saturation kinetics. The purpose of the uptake experiments undertaken in this study, however, was to determine whether $\mathrm{K}$ uptake is altered by exposure to different $\mathrm{K}$ concentrations other than by an effect due to affinity of $\mathrm{K}$ for the transporters; i.e., whether there is regulation of either the number or the activity of the cotransporters. To this purpose, two sets of experiments were designed. In the first set of experiments, plexuses were exposed to different $[\mathrm{K}]$ (for periods up to $1 \mathrm{~h}$ ) but were transferred back to con.rol | K | media for $30 \mathrm{~s}$ ( unless stated) for the measurement of ${ }^{86} \mathrm{Rb}$ uptake. In the second set, the rate of uptake was compared in choroid plexuses exposed to $1 \mathrm{mMK}$ for either 0.5 or $60 \mathrm{~min}$ and measurements of uptake were made in this media. Thus, in both sets of experiments, comparisons of uptake were made in media with the same $[\mathrm{K}]$.

As there was the possibility that choroid plexus $\mathrm{K}$ transport might change with the length of time after isolation, statistical comparisons were limited to plexuses isolated for

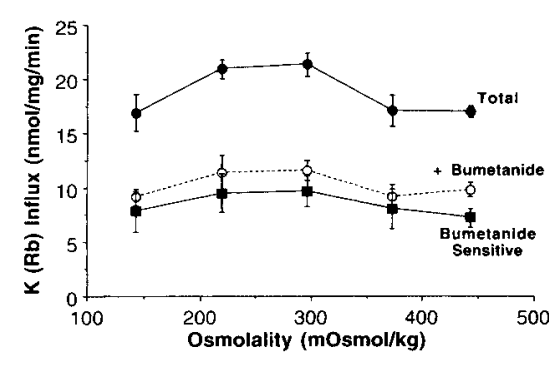

FIG. 1. The effect of 10-min exposure to media of different osmolalities on the rate of $\mathrm{K}\left({ }^{86} \mathrm{Rb}\right)$ influx into rat lateral ventricle choroid plexus. Measurements were made in the presence or absence of $30 \mu M$ bumetanide, which was added $30 \mathrm{~s}$ before the uptake measurement. All values are means $+\mathrm{SE} ; n=5-12$. The bumetanide-sensitive flux was calculated by subtracting the flux in the presence of bumetanide from the total (control) flux.

the same period of time. Where necessary, this was ensured by preincubating plexuses in control buffers for longer periods of time. As there was also the possibility of cell mortality either in response to the isolation or due to the exposure to different media, the release of a cytostolic enzyme, lactate dehydrogenase, into the external medium was used as a measure of membrane integrity. Lactate dehydrogenase concentrations were measured using a commercially available diagnostic kit (Sigma, St. Louis, MO, U.S.A.). This measures the lactate dehydrogenase-dependent conversion of pyruvic acid + NADH to lactic acid + NAD by determining pyruvic acid concentrations colorimetrically after reaction with 2,4dinitrophenylhydrazine. Lactate dehydrogenase release was compared with total tissuc concentrations obtained after disruption with an IK A-Ultra-Turrax T25 homogenizer (IKA. Cincinnati, OH, U.S.A.).

\section{Buffers}

Bicarbonate buffers were continuously bubbled with $5 \%$ $\mathrm{CO}_{2} / 95 \% \mathrm{O}_{2}$ and contained $127 \mathrm{mM} \mathrm{NaCl}, 20 \mathrm{mM}$ $\mathrm{NaHCO}_{3}, 2.4 \mathrm{~m} M \mathrm{KCl}, 0.5 \mathrm{~m} M \mathrm{KH}_{2} \mathrm{PO}_{4}, 1.1 \mathrm{mMCaCl}$, $0.85 \mathrm{mM} \mathrm{MgCl}, 0.5 \mathrm{~m} M \mathrm{Na}_{2} \mathrm{SO}_{4}$, and $5 \mathrm{~m} M$ glucose ( $\mathrm{pH}$ 7.4). Changes in $[\mathrm{K}]$ were achieved by substituting $\mathrm{NaCl}$ for $\mathrm{KCl}$. Changes in osmolality were obtained by altering the concentration of $\mathrm{NaCl}$.

\section{Materials}

Bumctanide was purchased from Sigma. Radioisotopes were supplied by New England Nuclear (Boston, MA, U.S.A.), ARC (St. Louis, MO, U.S.A.), or Amersham Life Science (Arlington Heights, IL. U.S.A.). Hyamine hydroxide and Cyloscint were purchased from ICN (Costa Mesa, CA, U.S.A.).

\section{Statistics}

All comparisons were made using analysis of variance with a Newman-Keuls multiple comparisons test. Differences were considered significant at the $p<0.05$ level (twotailed). Data presented in the text are given as mean $\pm \mathrm{SE}$ values.

\section{RESULTS}

\section{Osmolality and cotransport}

Changes in osmolality did not alter the rate of ${ }^{86} \mathrm{Rb}$ uptake significantly (either in the absence or presence of bumetanide; Fig. 1). However, the efflux rate con- 


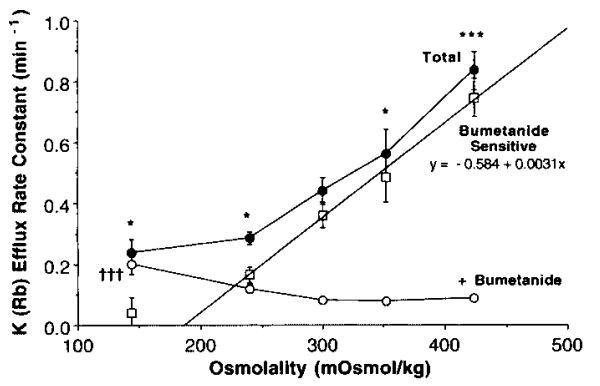

FIG. 2. Effect of 10-min exposure to media of different osmolalities on the efflux rate constant for $\mathrm{K}\left({ }^{86} \mathrm{Rb}\right)$ at the lateral ventricle choroid plexus. Measurements were made in the presence (open circles) or absence (filled circles) of $30 \mu M$ bumetanide, which was added $30 \mathrm{~s}$ before the efflux measurement. All values are means $\pm \mathrm{SE} ; \mathrm{n}=5-15 ;{ }^{*} p<0.05$ and ${ }^{\star \star *} p<0.001$, significant differences from control values without bumetanide; $\dagger \dagger \uparrow p$ $<0.001$, a significant difference from control values with bumetanide. Measurements in the presence and absence of bumetanide were used to calculate the bumetanide-sensitive flux (open squares). The regression analysis is for the bumetanide-sensitive flux measured at osmolalities $\geq 240 \mathrm{mOsm} / \mathrm{kg}$.

stant for ${ }^{86} \mathrm{Rb}$ rose progressively as buffer osmolality was increased by manipulation of $[\mathrm{NaCl}]$ (Fig. 2). This increase in efflux rate was wholly explained by an enhancement of the bumetanide-sensitive portion of the efflux. At osmolalities $>240 \mathrm{mOsm} / \mathrm{kg}$, there was an approximately linear relationship between the bumetanide-sensitive efflux rate and buffer osmolality (Fig. 2). An extrapolation of this relationship suggests the efflux cotransporter is inactivated at osmolalities $<190 \mathrm{mOsm} / \mathrm{kg}$. Efflux in the presence of bumetanide did not increase with osmolality. In fact, it was elevated at low osmolalities.

\section{Extracellular [ $\mathrm{K}]$ and cotransport}

Alterations in the $[\mathrm{K}\rfloor$ of the external media had a pronounced effect on choroid plexus $\mathrm{K}$ uptake (Fig. 3 ). In these experiments, choroid plexuses were exposed to different $\mathrm{K}$ concentrations for $1 \mathrm{~h}$ before being

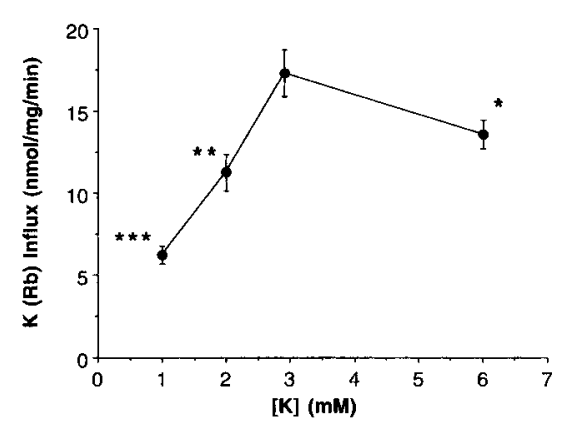

FIG. 3. The effect of $1-h$ exposure to media of different $K$ concentrations on the rate of $K\left({ }^{86} \mathrm{Rb}\right)$ uptake on return to control CSF $(2.9 \mathrm{mMK})$. All values are means $\pm \mathrm{SE} ; \mathrm{n}=5-11 ;{ }^{*} p$ $<0.05,{ }^{* \star} p<0.01,{ }^{* \star *} p<0.001$, significant differences from control $(2.9 \mathrm{mMK})$.

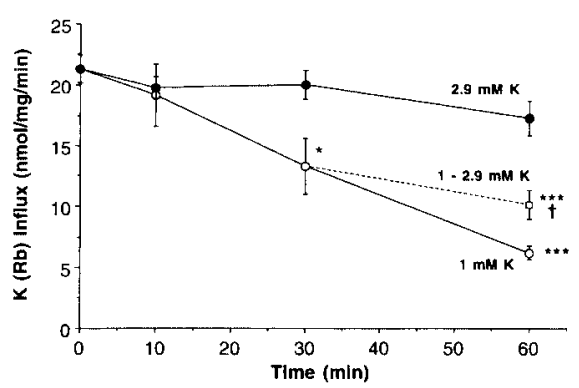

FIG. 4. The effect of different durations of exposure to 1 or 2.9 $\mathrm{mMK}$ artificial CSF on the rate of $\mathrm{K}$ influx in choroid plexuses $30 \mathrm{~s}$ after transfer to control $(2.9 \mathrm{mMK}) \mathrm{CSF}$. Also shown is the effect on $\mathrm{K}$ uptake of 30-min exposure to $1 \mathrm{mM} \mathrm{K}$ followed by $30 \mathrm{~min}$ in $2.9 \mathrm{mMK}$. All values are means $\pm \mathrm{SE} ; \mathrm{n}=5-12$; ${ }^{*} p<0.05,{ }^{* \star *} p<0.001$, significant differences from control measurements at the same time point; $\nmid p<0.05$, significant difference from plexuses exposed to $1 \mathrm{mMK}$.

transferred back into control media $(2.9 \mathrm{~m} M \mathrm{~K})$ for ${ }^{86} \mathrm{Rb}$ uptake measurements. The rate of $\mathrm{K}$ uptake progressively declined as the choroid plexuses were exposed to lower $\mathrm{K}$ concentrations, with $1 \mathrm{~m} M \mathrm{~K}$ inducing a $64 \%$ reduction $(p<0.001$; Fig. 3$)$. There was also a slight, but significant $(p<0.05)$, decrease in $\mathrm{K}$ uptake in plexuses exposed to a high $[\mathrm{K}]$ media (6 $\mathrm{m} M)$.

The time course of the effect of low $[\mathrm{K}](1 \mathrm{mM})$ on $\mathrm{K}$ uptake was examined with all measurements being made on return to control buffer. After 10-min exposure there was no significant effect on the rate of uptake compared with a time-matched control (Fig. 4). By $30 \mathrm{~min}$, however, uptake was suppressed and this effect was even greater at $60 \mathrm{~min}$. The reversibility of this process was examined using plexuses exposed to $1 \mathrm{~m} M \mathrm{~K}$ for $30 \mathrm{~min}$ before being transferred back to control buffer for $30 \mathrm{~min}$. This procedure did not return the uptake to control values, but it did prevent the further decline in uptake that occurred during 60 min exposure to $1 \mathrm{~m} M \mathrm{~K}$ (Fig. 4).

The mechanism for the reduction in $\mathrm{K}$ uptake in 1 $\mathrm{m} M \mathrm{~K}$ was examined in two sets of experiments. In the first, $\mathrm{K}$ uptake was measured in plexuses exposed to $60 \mathrm{~min}$ of $\mathrm{I}$ or $2.9 \mathrm{mM} \mathrm{K}$ followed by $30 \mathrm{~s}$ in control $(2.9 \mathrm{~m} M \mathrm{~K})$ CSF with or without ouabain or bumetanide before the measurement of $\mathrm{K}\left({ }^{86} \mathrm{Rb}\right)$ uptake. In plexuses exposed to $2.9 \mathrm{~m} M \mathrm{~K}$ for $\mathrm{I} \mathrm{h}$, ouabain and bumetanide $(p<0.001)$ reduced the $\mathrm{K}$ uptake by $\sim 53$ and $\sim 33 \%$, respectively. In plexuses exposed to I $\mathrm{m} M \mathrm{~K}$, the ouabain-insensitive flux was reduced from $8.1 \pm 0.5$ to $1.2 \pm 0.7 \mathrm{nmol} / \mathrm{mg} / \mathrm{min}(p<0.001)$ and there was no longer a significant reduction in uptake in the presence of bumetanide (Fig. 5A).

In the second procedure, the reverse experiment was performed. Plexuses were exposed to $60 \mathrm{~min}$ of 1 or $2.9 \mathrm{~m} M \mathrm{~K}$ followed by $30 \mathrm{~s}$ in $1 \mathrm{~m} M \mathrm{~K} \mathrm{CSF}$ with or without ouabain or bumetanide before the measurement of $\mathrm{K}$ uptake. In these experiments, total $\mathrm{K}$ influx 
A

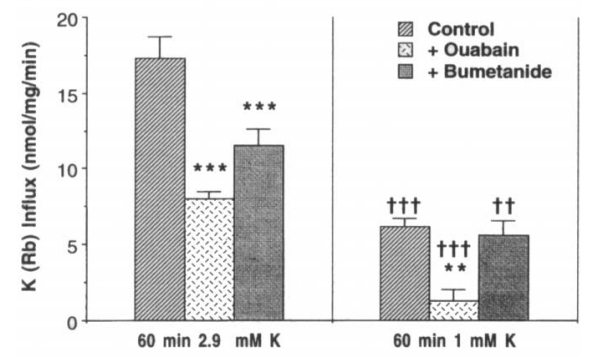

B

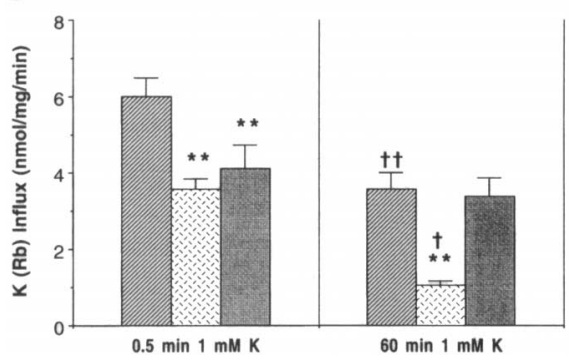

FIG. 5. Effect of exposure to $1 \mathrm{~m} M \mathrm{~K}$ on choroid plexus $\mathrm{K}$ uptake measured in the presence or absence of ouabain $(5 \mathrm{mM})$ or bumetanide $(30 \mu M)$. A: $\mathrm{K}\left({ }^{86} \mathrm{Rb}\right)$ uptake in plexuses exposed to either control $(2.9 \mathrm{mMK}$ ) or $1 \mathrm{mMK}$ artificial CSF for $1 \mathrm{~h}$. Uptake measurements were made $30 \mathrm{~s}$ after transfer to fresh $2.9 \mathrm{~m} M$ CSF. B: $\mathrm{K}$ uptake in plexuses exposed to $1 \mathrm{~m} M \mathrm{~K}$ for 0.5 or $60 \mathrm{~min}$. Values are means $\pm \mathrm{SE} ; \mathrm{n}=5-9 ;{ }^{*} p<0.01$ and ${ }^{* * *} p<0.001$, compared with respective controls with the same duration of exposure to $1 \mathrm{mMK} ; \dagger p<0.05$, $\dagger \dagger p<0.01$, compared with same condition in plexuses exposed to $1 \mathrm{mMK}$ for $0.5 \mathrm{~min}$.

rate was reduced from $6.0 \pm 0.5 \mathrm{nmol} / \mathrm{mg} / \mathrm{min}$ in plexuses exposed to $1 \mathrm{mMK}$ for $30 \mathrm{~s}$ to $3.6 \pm 0.4 \mathrm{nmol} /$ $\mathrm{mg} / \mathrm{min}$ in plexuses exposed for $1 \mathrm{~h}(p<0.01$; Fig. $5 \mathrm{~B}$ ). This was due to a reduction in the ouabain-insensitive flux from $(3.6 \pm 0.3$ to $1.1 \pm 0.1 \mathrm{nmol} / \mathrm{mg} / \mathrm{min}$; $p<0.05)$. Again, plexuses with prolonged exposure to $1 \mathrm{~m} M \mathrm{~K}$ had no significant reduction in $\mathrm{K}$ uptake in the presence of bumetanide (Fig. 5B).

One difference in the results between the two procedures, measurements in 2.9 and $1 \mathrm{~m} M \mathrm{~K}$, was that in the former, prolonged exposure to $1 \mathrm{~m} M \mathrm{~K}$ also produced a slight reduction in the uptake measured in the presence of bumetanide (i.e., bumetanide-insensitive; Fig. 5A). When determinations were made in $1 \mathrm{~m} M$ $\mathrm{K}$, however, there was no reduction in bumetanideinsensitive uptake after 1 -h exposure compared with measurements after $30 \mathrm{~s}$ (Fig. 5B).

Altering external medium $[\mathrm{K}]$ to 1 or $6 \mathrm{~m} M$ had no significant effect on the efflux rate constant for $\mathrm{K}$ $\left({ }^{86} \mathrm{Rb}\right)$ at the choroid plexus (Table 1$)$. This was the case whether the measurements were made in the presence of the altered $[\mathrm{K}]$ or after the return of the plexus to control buffer for $30 \mathrm{~s}$ before the efflux determination. Choroid plexuses exposed to $6 \mathrm{~m} M \mathrm{~K}$ did, however, have a slightly greater bumetanide-insensitive ef- flux rate constant compared to controls whether the measurement was made at $6 \mathrm{~m} M \mathrm{~K}(p<0.01)$ or after return to $2.9 \mathrm{~m} M \mathrm{~K}$ media $(p<0.05)$.

To examine whether the alterations in choroid plexus $\mathrm{K}$ transport in response to changes in [K] might result from reduced membrane integrity, lactate dehydrogenase release was measured. The percentage of total choroid plexus lactate dehydrogenase released during $1 \mathrm{~h}$ of incubation in $1,2,2.9$, and $6 \mathrm{~m} M \mathrm{~K}$ was $10.2 \pm 0.9,11.0 \pm 0.5,6.1 \pm 0.4$, and $10.4 \pm 2.8 \%$, respectively $(n=4-5)$. These values were not significantly different.

\section{DISCUSSION}

The choroid plexus epithelium has a high density of Na/K pumps, $\sim 3$ million/cell (Wright, 1978). Yet, $\mathrm{K}$ uptake by bumetanide-sensitive cotransport is approximately equal to that via the $\mathrm{Na} / \mathrm{K}$ pump and the rate of bumetanide-sensitive $\mathrm{K}$ efflux is probably greater than either (Keep et al., 1994). Despite its quantitative magnitude, the function of $\mathrm{K}$ cotransport at the choroid plexus is uncertain. The results presented in this study suggest that $\mathrm{K}$ cotransport may play a role in both volume and $\mathrm{K}$ regulation in the CNS. However, it appears that whereas volume regulation may involve alterations in outward cotransport, $\mathrm{K}$ regulation may involve the inward component. Although others have shown that imposing ion gradients can drive $\mathrm{K}$ cotransport in both directions in other cell types (e.g., Gargus and Slayman, 1980; Altamirano and Russell, 1987), we are unaware of another cell type where both directions appear to be separately regulated and have separate physiological functions.

\section{Cotransporter: type and location}

The interpretation of the physiological importance of the results obtained in this study depends upon the location of the $\mathrm{K}$ cotransporter or cotransporters, whether the inward and outward $K$ transport are via the same mechanism, and whether that mechanism is of the $\mathrm{KCl}$ or $\mathrm{Na} / \mathrm{K} / \mathrm{Cl}$ form. Much of the evidence for our belief that there is an apically situated $\mathrm{Na} / \mathrm{K}$ / $2 \mathrm{Cl}$ cotransporter that moves $\mathrm{K}$ into and out of the choroid plexus epithelial cells is outlined in Keep et al. (1994). In brief, bumetanide, an inhibitor of either $\mathrm{Na} / \mathrm{K} / \mathrm{Cl}$ or $\mathrm{KCl}$ cotransport, reduces $\mathrm{K}, \mathrm{Na}$, and $\mathrm{Cl}$ influx into isolated rat choroid plexus (Johanson et al., 1990; Bairamian et al., 1991; Keep et al., 1994), the bumetanide-sensitive portion of $\mathrm{K}\left({ }^{86} \mathrm{Rb}\right)$ influx is absent if external $\mathrm{Na}$ is removed (Keep et al., 1994), and the bumetanide-sensitive influx of $\mathrm{Na}, \mathrm{K}$, and $\mathrm{Cl}$ are in the ratio of approximately 1:1:2 (Johanson et al., 1990; Keep et al., 1994) as expected from an Na/ $\mathrm{K} / 2 \mathrm{Cl}$ cotransporter found in many tissues. In a similar manner, in the rat, there is bumetanide-sensitive $\mathrm{K}$, $\mathrm{Na}$, and $\mathrm{Cl}$ efflux (Preston et al., 1993; Keep et al., $1994) ; R(+)$-butylindazone, an inhibitor of $\mathrm{KCl} \mathrm{co-}$ 
TABLE 1. Efflux rate constant for $K$ on exposure to media of different [ $K$ ]

\begin{tabular}{|c|c|c|c|c|}
\hline & \multicolumn{4}{|c|}{ Efflux rate constant $\left(\mathrm{min}^{-1}\right)$} \\
\hline & $\begin{array}{c}\text { - Bumetanide } \\
\text { (media) }\end{array}$ & $\underset{\text { (media) }}{+ \text { Bumetanide }}$ & $\begin{array}{c}\text { - Bumetanide } \\
\text { (2.9 } M M \mathrm{~K})\end{array}$ & $\begin{array}{l}\text { + Bumetanide } \\
(2.9 \mathrm{~m} M \mathrm{~K})\end{array}$ \\
\hline $1 \mathrm{~m} M \mathrm{~K}$ & $0.442 \pm 0.030$ & $0.105 \pm 0.016$ & $0.411 \pm 0.065$ & $0.098 \pm 0.006$ \\
\hline $2.9 \mathrm{mM} \mathrm{K}$ & $0.493 \pm 0.048$ & $0.078 \pm 0.010$ & - & - \\
\hline $6 \mathrm{~m} M \mathrm{~K}$ & $0.379 \pm 0.014$ & $0.164 \pm 0.04 I^{\prime \prime}$ & $0.412 \pm 0.089$ & $0.134 \pm 0.021^{\prime \prime}$ \\
\hline
\end{tabular}

Efflux rate constant for $\mathrm{K}\left({ }^{\mathrm{o} 6} \mathrm{Rb}\right)$ in the absence or presence of bumetanide $(30 \mu M)$ measured after a 1-h exposure to CSF with different $\mathrm{K}$ concentrations. Measurements were either made in these media or after 30 -s exposure to fresh control $(2.9 \mathrm{mM} \mathrm{K}) \mathrm{CSF}$. Values are means $\pm \mathrm{SE} ; \mathrm{n}=5$.

" $p<0.01$ and " $p<0.05$, values significantly different from the control $(2.9 \mathrm{~m} M \mathrm{~K})$ + bumetanide.

transport, had no effect on K efflux (Keep et al., 1994), but increasing intracellular or extracellular $\mathrm{Na}$ enhanced the bumetanide-sensitive efflux (Keep et al., 1994). In total, this suggests the $\mathrm{K}$ cotransport efflux mechanism is of the $\mathrm{Na} / \mathrm{K} / \mathrm{Cl}$ form, and we have postulated that it is the same as the inward transporter operating in both directions (Keep et al., 1994). In contrast to other tissues, efflux through the cotransporter is greater than influx in the rat choroid plexus (Keep et al., 1994). This probably is due to a very high density of $\mathrm{Cl} / \mathrm{HCO}_{3}$ exchangers in this tissue (Lindsey et al., 1990) that results in a relatively high intracellular chloride concentration (Smith and Johanson, 1985 ) compared with other tissues and an electrochemical gradient favoring efflux through the transporter.

As to the location of a cotransporter, Zeuthen (1991 $a, b)$ has provided substantial evidence that there is an apically located efflux $\mathrm{K}$ cotransporter in Necturus choroid plexus. In the isolated rat choroid plexus, $\mathrm{K}$ cotransport and $\mathrm{Na}, \mathrm{K}-\mathrm{ATPase}$ are the main $\mathrm{K}$ influx mechanisms (Keep et al., 1994). The rate of K efflux through the cotransporter is greater than either uptake mechanism alone (Keep et al., 1994); thus, if only the $\mathrm{Na}, \mathrm{K}-\mathrm{ATPase}$ were located on the apical membrane, there would be a substantial net efflux of $K$ across the apical membrane and a K-rich CSF. This is not the case, suggesting that the influx cotransporter is also apically located and may be the efflux cotransporter operating in both directions. The experiments presented in this study do not directly provide evidence as to the location of the cotransporter. However, we believe that if the osmotic and ionic effects described were on an apically located cotransporter, they would best agree with previously reported in vivo data on brain ion and fluid balance regulation (see below).

\section{Cotransport and volume regulation}

Many cell types modulate $\mathrm{K}$ transport as a volumeregulatory mechanism. This involves an increased uptake via $\mathrm{K}$ cotransport during hyperosmotic stress to limit cell shrinkage and an increase in $\mathrm{K}$ efflux during hypoosmotic stress to limit cell swelling (Geck and Heinz, 1986). The latter may in some cells involve the activation of $\mathrm{K}$ cotransport (Garay et al., 1988). In contrast, the choroid plexus shows the opposite effect, an increase in outward $\mathrm{K}$ cotransport with increasing osmolality. This study in a mammalian species complements that of Zeuthen (1991b) in an amphibian, Necturus, who also found an increase in $\mathrm{K}$ cotransport efflux in response to hyperosmotic stress. The reason for this difference may lie in the role of the choroid plexus as a barrier tissue. Thus, whereas other cells increase ion influx during hyperosmotic stress to maintain cell volume, the choroid plexus may increase efflux via the cotransporter to move solutes into the brain and, thus, help to maintain brain volume.

Thus, although plasma hyperosmolality causes a loss of water from the brain, this loss is less than expected from a tissue that does not volume regulate due to a net gain in brain solutes that limits the water loss necessary for osmotic equilibrium between blood and brain (reviewed in Cserr and Patlak, 1991). At least during short-term changes in osmolality, $\mathrm{Na}, \mathrm{Cl}$, and $\mathrm{K}$ appear to be the main solutes gained during hyperosmotic stress (e.g., Cserr et al., 1987a; Keep et al., 1993b). Such solutes must traverse the blood-brain or blood$\mathrm{CSF}$ barrier to move from blood to brain. If the Kcotransport efflux pathway is an $\mathrm{Na} / \mathrm{K} / 2 \mathrm{Cl}$ cotransporter situated on the apical membrane of the choroid plexus, as we have hypothesized (Keep et al., 1994), an increase in efflux from the choroid plexus epithelium through this mechanism could participate in the net uptake of these ions during hyperosmotic stress. It is interesting that hyperosmotic stress results in an increase in CSF [K] (Bradbury and Kleeman, 1969) and an increase in the rate of blood to CSF $\mathrm{K}\left({ }^{86} \mathrm{Rb}\right)$ transport (unpublished observation) that might result from stimulation of a choroid plexus K-cotransport pathway if it were present on the apical membrane.

The results presented in this study enable an estimate of the importance of the choroid plexus cotransporter in brain volume regulation during hyperosmotic stress 
in the rat. Increasing media osmolality from 300 to $360 \mathrm{mOsm} / \mathrm{kg}$ increases the efflux rate constant via the cotransporter by $\sim 0.2 \mathrm{~min}^{-1}$. Assuming an epithelial intracellular [K] of $140 \mathrm{~m} M$ and an epithelial volume of $1.8 \mu \mathrm{l} / \mathrm{g}$ of brain [derived from Johanson and Murphy (1990) assuming $3 \mathrm{mg}$ of plexus/g brain], this would increase the efflux of $\mathrm{K}$ into the CSF by $\sim 3$ $\mu \mathrm{mol} / \mathrm{g} / \mathrm{h}$. This compares with measured increases in brain $\mathrm{K}$ content of $\sim 10 \mu \mathrm{mol} / \mathrm{g}$ during an hour of a similar osmotic stress in vivo (Keep et al., 1993b). The remaining uptake might be due to changes in blood-brain barrier ion transport. Cserr et al. (1987b) have reported an increase in blood-brain barrier $\mathrm{K}$ transport in response to hyperosmotic stress. Whether $\mathrm{K}$ cotransport is involved in blood-brain barrier $\mathrm{K}$ transport is a matter of controversy (Keep et al., $1993 a$ ).

Alterations in $\mathrm{K}$ cotransport may serve to limit brain volume changes during osmotic stress other than by limiting the osmotic shifts of water necessary to maintain isosmolality between blood and brain. Zeuthen $(1991 a, b)$ has shown in the amphibian choroid plexus that $\mathrm{K}$ cotransport is intimately linked to fluid secretion. In mammalian species, intracerebroventricular infusion of bumetanide can also reduce CSF secretion rate (Johnson et al., 1987; Javaheri and Wagner, 1993 ). This suggests that changes in osmolality, by affecting $\mathrm{K}$-transport activity, may alter CSF secretion rate.

Indeed, Wald et al. (1976) found that there was a positive linear relation between CSF osmolality and CSF bulk flow in the cat. The slope of this relation was decreased by $\sim 60 \%$ in the presence of acetazolamide, an inhibitor of carbonic anhydrase, suggesting an involvement of active secretion. It is interesting that Wald et al. (1976) also found no effect of acetazolamide on CSF flow at a CSF osmolality of $190 \mathrm{mOsm} /$ $\mathrm{kg}$. This is in very close agreement to the osmotic sensitivity of the $\mathrm{K}$ cotransporter presented here. It was also abolished at osmolalities below $\sim 190 \mathrm{mOsm} / \mathrm{kg}$. Acetazolamide may act indirectly to diminish K-efflux cotransport by altering the electrochemical gradients for $\mathrm{Na}$ and $\mathrm{Cl}$ via an inhibition of basolateral $\mathrm{Na} / \mathrm{H}$ and $\mathrm{Cl} / \mathrm{HCO}_{3}$ exchange. We have found that prolonged exposure to an inhibitor of $\mathrm{Cl} / \mathrm{HCO}_{3}$ exchange, 4-4' diisothiocyanatostilbene-2,2'-disulfonic acid, also inhibits K-efflux cotransport (unpublished observations).

This study does not examine directly how hyperosmotic stress increases efflux $\mathrm{K}$ cotransport. Whether these changes are due purely to changes in the electrochemical gradients for $\mathrm{K}, \mathrm{Na}$, and $\mathrm{Cl}$ or whether cotransport is regulated by other factors is uncertain. In vivo, the choroid plexus has many neuroendocrine inputs (Nilsson et al., 1992) and some of these, particularly those postulated to be involved in brain volume regulation, might also regulate this cotransporter.

Unlike the efflux via the $K$ cotransporter, bumeta- nide-insensitive flux was increased in low osmolalities. This may reflect an opening of a $\mathrm{K}$ channel as part of epithelial cell volume regulation. Christensen (1987) has described a stretch-activated nonselective cation channel in choroid plexus.

\section{Cotransport and $K$ regulation}

In contrast to the osmotic effects described above, reductions in extracellular $\mathrm{K}$ concentration affected bumetanide-sensitive uptake and not efflux. Before discussing the possible physiological importance of this finding, it is important to assess whether this is a direct effect on transport or whether it might be explained by a decreased viability of the tissue in $1 \mathrm{~m} M \mathrm{~K}$. The following four observations suggest that the latter is not the case: (1) $1 \mathrm{~m} M \mathrm{~K}$ appears to selectively reduce the bumetanide-sensitive portion of the flux (Fig. 5B) but (2) has no effect on the efflux rate constant. (3) We examined whether a recovery period in control $\mathrm{CSF}$ would alter the ${ }^{86} \mathrm{Rb}$ uptake. Thirty minutes of exposure to $2.9 \mathrm{~m} M \mathrm{~K}$ after $30 \mathrm{~min}$ in $1 \mathrm{~m} M \mathrm{~K}$ did not result in a return of the rate of uptake to a control value. It did, however, prevent the further decline in uptake that occurred by $60 \mathrm{~min}$ of $1 \mathrm{~m} M \mathrm{~K}$ exposure. (4) Finally, cell viability, as measured with lactate dehydrogenase, was not significantly affected by a 1$\mathrm{h}$ exposure to media with $\mathrm{K}$ concentrations varying from 1 to $6 \mathrm{~m} M$. If the reduction in $\mathrm{K}$ uptake found in $1 \mathrm{~m} M \mathrm{~K}$ were due solely to cell lysis, a $65 \%$ release of lactate dehydrogenase would have been expected.

Alterations in external $[\mathrm{K} \mid$ can affect $\mathrm{K}$ transport at the choroid plexus because of the affinity of $K$ for the transporters (Parmelee et al., 1991 ) and, therefore, all comparisons made in this study were between measurements made in buffers with the same $[\mathrm{K}]$. In particular, comparisons were made of measurements after transfer of choroid plexuses back to $2.9 \mathrm{mM} \mathrm{K}$ or during different durations of exposure to $1 \mathrm{~m} M \mathrm{~K}$. In both protocols, we found the bumetanide-sensitive portion of uptake to be abolished in choroid plexuses given prolonged exposure to $1 \mathrm{~m} M \mathrm{~K}$. The only qualitative difference in the results between the two protocols was that uptake measured in the presence of bumetanide was also slightly reduced in plexuses returned to $2.9 \mathrm{~m} M \mathrm{~K}$ from a 1 -h exposure to $1 \mathrm{~m} M \mathrm{~K}$, whereas there was no effect on this parameter in plexuses maintained in $1 \mathrm{~m} M \mathrm{~K}$ for $1 \mathrm{~h}$ compared with those exposed for $30 \mathrm{~s}$. The reason for this difference is uncertain.

We have suggested (Keep et al., 1994) that the influx of $\mathrm{K}$ via the cotransporter occurs at the apical membrane of the choroid plexus epithelium. If this is the case, the abolition of inward $\mathrm{K}$ cotransport in response to I $\mathrm{m} M \mathrm{~K}$ may be a CSF $\mathrm{K}$ homeostatic mechanism, because it would inhibit the removal of $\mathrm{K}$ from the CSF when CSF $[\mathrm{K}]$ is low. It is known in vivo that the $[\mathrm{K}]$ of newly formed $\mathrm{CSF}$ varies inversely 
with the $\mathrm{K}$ concentration of the CSF bathing the choroid plexus (Husted and Reed, 1976).

The reduction in $\mathrm{K}$ transport in response to low $\mathrm{K}$ was progressive over the course of $1 \mathrm{~h}$. Thus, it is unlikely that this mechanism is involved in minute-tominute regulation of CSF [K]. Parmelee et al. (1991) have shown that $\mathrm{K}$ uptake by isolated choroid plexuses shows saturation kinetics with a $K_{\mathrm{n}}$ of between 3 and $6 \mathrm{~m} M \mathrm{~K}$ close to the normal CSF [K] of $2.9 \mathrm{~m} M$. This suggests that increases in CSF $[\mathrm{K}]$ will enhance directly $\mathrm{K}$ efflux from the CSF and contribute to CSF $\mathrm{K}$ homeostasis. In contrast, synaptosomal $\mathrm{Na}, \mathrm{K}-$ ATPase has a $K_{\mathrm{m}}$ of $0.47 \mathrm{~m} M$, suggesting that it is saturated at normal physiological concentrations (Schielke et al., 1990). Other than transporters, K channels may also play a role in CSF $\mathrm{K}$ homeostasis. The enhanced $\mathrm{K}$ efflux through a bumetanide-insensitive mechanism in response to $6 \mathrm{~m} M \mathrm{~K}$ might reflect an opening of a $\mathrm{K}$ channel. Whole-cell patch-clamp studies on rat choroid plexus epithelial cells have found a $\mathrm{K}$ channel that is activated by cell depolarization (Kotera and Brown, 1994). Whether this channel is apically or basolaterally situated is unknown.

How the rate of $\mathrm{K}$-cotransport efflux is altered by the reduction in extracellular [ $\mathrm{K}]$ has still to be elucidated. The apical membrane of the epithelium is much more $\mathrm{K}$ permeable than the basolateral membrane (Zeuthen and Wright, 1981) and may respond to changes in external $\mathrm{K}$ in a manner similar to a $\mathrm{K}$ electrode. It is possible, therefore, that $\mathrm{K}$ transport is altered in response to the potential across this membrane either via a direct effect on the transport protein or as an indirect effect due to the release of a second messenger. Whether the alteration in $\mathrm{K}$ cotransport is due to a change in the number or the activity of individual transporters is also unknown, although the cloning of the $\mathrm{Na} / \mathrm{K} / 2 \mathrm{Cl}$ cotransporter should facilitate such studies.

\section{Conclusion}

The results presented suggest that choroid plexus cotransport plays an important role in both brain volume regulation and $\mathrm{CSF}[\mathrm{K}]$ homeostasis. A greater knowledge of choroid plexus cotransports function and control might lead to a better understanding and treatment of diseases associated with increases in brain volume, such as ischemia and hydrocephalus. It may also help in our understanding of mineralocorticoid hypertension, as a recent study has suggested that the development of such hypertension is linked to an alteration in CSF K homeostasis (Klarr et al., 1995).

Acknowledgment: This study was aided by Basic Research grant no. 1-FY91-0-131 from the March of Dimes Birth Defects Foundation and by grant HL-18575 from the National Institutes of Health. We thank Dr. A. Lorris Betz for many helpful comments and suggestions.

\section{REFERENCES}

Altamirano A. A. and Russell J. M. ( 1987 ) Coupled Na/K/Cl efflux. "Reverse" unidirectional fluxes in squid giant axons. J. Gen. Physiol. 89, 669-686.

Bairamian D., Johanson C. E., Parmelee J. T., and Epstein M. H. (1991) Potassium cotransport with sodium and chloride in the choroid plexus. I. Neurochem. 56, 1623-1629.

Bradbury M. W. B. (1979) The Concept of a Blood-Brain Barrier, pp. 1-465. John Wiley \& Sons, Chichester.

Bradbury M. W. B. and Kleeman C. R. (1967) Stability of the potassium content of cerebrospinal fluid and brain. Am. J. Physiol. 213, 519-528.

Bradbury M. W. B. and Kleeman C. R. (1969) The effect of chronic osmotic disturbance on the concentrations of cations in cerebrospinal thuid. J. Physiol. (Lond.) 204, 181-189.

Christensen O. (1987) Mediation of cell volume regulation by $\mathrm{Ca}^{2}$ influx through stretch-activated channels. Nature 330, 66-68.

Cserr H. F. and Patlak C. S. (1991) Regulation of brain volume under isosmotic and anisosmotic conditions, in Advances in Comparative and Environmental Physiology (Gilles R., ed), pp. 61-80. Springer-Verlag, Berlin, Heidelberg.

Cserr H. F., DePasquale M., and Patlak C. S. (1987a) Regulation of brain water and electrolytes during acute hyperosmolality in rats. Am. J. Physiol. 253, F522-F529

Cserr H. F., DePasquale M., and Patlak C. S. (1987b) Volume regulatory influx of electrolytes from plasma to brain during acute hyperosmolality. Am. J. Physiol. 253, F530-F537.

Garay R. P., Nazaret C., Hannaert P. A., and Cragoe E. J. (1988) Demonstration of a $\left[\mathrm{K}^{+}, \mathrm{Cl}^{-}\right]$-cotransport system in human red cells by its sensitivity to / (dihydroindenyl) oxy lalkanoic acids: regulation of cell swelling and distinction from the bumetanide sensitive $\left.\mid \mathrm{Na}^{+}, \mathrm{K}^{+}, \mathrm{Cl}^{-}\right]$-cotransport system. Mol. Pharmacol. 33, 696-701.

Gargus J. J. and Slayman C. W. (1980) Mechanism and role of furosemide-sensitive $\mathrm{K}^{+}$transport in $\mathrm{L}$ cells: a genetic approach. J. Membr. Biol. 52, 245-256.

Geck P. and Heinz E. ( 1986 ) The Na-K-2Cl cotransport system. J. Membr. Biol. 91, 97-105.

Husted R. F. and Reed D. J. (1976) Regulation of cerebrospinal fluid potassium by the cat choroid plexus. J. Physiol. 259, $213-$ 221.

Javaheri S. and Wagner K. R. (1993) Bumetanide decreases canine cerebrospinal fluid production. In vivo evidence for $\mathrm{NaCl}$ cotransport in the central nervous system. J. Clin. Invest. 92, $2257-226$ l.

Johanson C. E. and Murphy V. A. ( 1990 ) Acetazolamide and insulin alter choroid plexus epithelial cell $\left[\mathrm{Na}^{+}\right], \mathrm{pH}$ and volume. $\mathrm{Am}$. J. Physiol. 258, F1538-F1546.

Johanson C. E. and Preston J. E. (1994) Potassium efflux from infant and adult rat choroid plexuses: effects of CSF anion substitution, $\mathrm{N}$-ethylmaleimide and $\mathrm{Cl}$ transport inhibitors. Neurosci. Lett. 169, 207-211.

Johanson C. E., Sweeney S. M., Parmelee J. T., and Epstein M. H. (1990) Cotransport of sodium and chloride by adult mammalian choroid plexus. Am. J. Physiol. 258, C211-C216.

Johnson D. C., Singer S., Hoop B., and Kazemi H. ( 1987) Chloride flux from blood to CSF: inhibition by furosemide and bumetanide. Am. J. Physiol. 63, 1591-1600.

Jones H. C. and Keep R. F. (1987) The control of potassium concentration in the cerebrospinal fluid and brain interstitial fluid of developing rats. J. Physiol. (Lond.) 383, $441-453$.

Keep R. F., Xiang J., and Betz A. L. (1993a) Potassium transport at the blood-brain and blood-CSF barriers. Adv. Exp. Med. Biol. 331, $43-54$.

Keep R. F., Xiang J., Ennis S. R., Beer M. E., and Betz A. L. (1993b) Brain volume regulation during development: the role of blood-brain barrier potassium transport. Adv. Exp. Med. Biol. 331, 65-69.

Keep R. F., Xiang J., and Betz A. L. ( 1994 ) Potassium cotransport at the rat choroid plexus. Am. J. Physiol. 267, C1616-C1622. 
Klarr S. A., Keep R. F., and Betz A. L. (1995) Chronic central potassium infusion prevents deoxycorticosterone-salt hypertension in rats. Am. J. Physiol. (in press).

Kotera T. and Brown P. D. (1994) Evidence for two types of potassium current in rat choroid plexus epithelial cells. Pflugers Arch 427, 317-324

Lindsey A. E., Schneider K., Simmons D. M., Baron R., Lee B. S. and Kopito R. R. (1990) Functional expression and subcellula localization of an anion exchanger cloned from choroid plexus. Proc. Natl. Acad. Sci. USA 87, 5278-5282.

Nilsson C., Lindvall-Axelsson M., and Owman C. (1992) Neuroendocrine regulatory mechanisms in the choroid plexus-cerebrospinal fluid system. Brain Res. Rev. 17, 109-138.

Parmelee J. T., Bairamian D., and Johanson C. E. ( 1991) Response of infant and adult rat choroid plexus potassium transporters to increased extracellular potassium. Dev. Brain Res. 60, 229233.

Preston J. E., Dyas M., and Johanson C. E. ( 1993) Development of chloride transport by the rat choroid plexus, in vitro. Brain Res. 624, $181-187$.

Schielke G. P., Moises H. C., and Betz A. L. (1990) Potassium activation of the Na,K-pump in isolated brain microvessels and synaptosomes. Brain Res. 524, 291-296.
Smith Q. R. and Johanson C. E. ( 1985 ) Active transport of chloride by lateral ventricle choroid plexus of the rat. Am. J. Physiol. 249, F470-F477

Stummer W., Keep R. F., and Betz A. L. (1994) Rubidium entry into brain and cerebrospinal fluid during acute and chronic alterations in plasma potassium. Am. J. Physiol. 266, H2239$\mathrm{H} 2246$.

Wald A., Hochwald G. M., and Malhan C. (1976) The effects of ventricular fluid osmolality on bulk flow of nascent fluid into the cerebral ventricles of cats. Exp. Brain Res. 25, 157-167.

Wright E. M. (1978) Transport processes in the formation of the cerebrospinal fluid. Rev. Physiol. Biochem. Pharmacol. 83, 1 34.

Zeuthen T. (1991a) Secondary active transport of water across ventricular cell membrane of choroid plexus epithelium of Necturus maculosus. J. Physiol. (Lond.) 444, 153-173.

Zcuthen T. (1991 $b$ ) Water permeability of ventricular cell membrane in choroid plexus epithelium from Necturus maculosus. J. Physiol. (Lond.) 444, 133-151.

Zeuthen T. and Wright E. M. (1981) Epithelial potassium transport: tracer and electrophysiological studies in choroid plexus. $J$. Membr. Biol. 60, 105-128. 